\title{
Responsibilities of a Notary in Concerning Making an Authentic Deed Based on Falsification of Letters by One of the Parties
}

\author{
Farman Riantama Budi*), Aryani Witasari ${ }^{* *}$ and Ngadino ${ }^{* * *}$ ) \\ *) Student Master of Notary Law, Faculty of Law, Universitas Islam Sultan Agung \\ Semarang, Indonesia, E-mail: farmanriantama@yahoo.co.id \\ ${ }^{* *}$ Lecturer Master of Notary Law, Faculty of Law, Universitas Islam Sultan \\ Agung \\ Semarang, Indonesia \\ ***) Lecturer Master of Notary Law, Faculty of Law, Universitas Islam Sultan \\ Agung Semarang, Indonesia
}

\begin{abstract}
This research aims to know the responsibilities of the notary in the event of letter forgery by the parties in making the authentic deed and whether a notary can be held responsible for a criminal case if a loss occurs to one of the parties as a result of a false document from one of the parties. The approach method in this research is empirical juridical method. The specification of this research is descriptive analytic. The data in this study are primary data and secondary data. These problems are analyzed using the theory of authority, theory of legal responsibility. Based on the results of that research when a Notary in carrying out his position is proven to have committed a violation, then the Notary is responsible according to his actions, both in terms of Administrative Law, Civil Law, namely in accordance with the provisions of the sanctions contained in Articles 84 and 85 of the Law on Amendments to the Law on the Position of Notary Public and code of conduct. A notary cannot be held responsible for a criminal case if there is a loss to one of the parties as a result of a false document from one of the parties, because the notary only records what is conveyed by the parties to be put into deeds false information submitted by the parties is the responsibility of the parties. In other words, what can be accountable to the Notary is if the fraud or deception originates from the Notary himself.
\end{abstract}

Keywords: Notary Responsibilities; Letter Forgery; Criminal Act.

\section{Introduction}

Notary as the hand of the state where the deed made by or in front of him is an authentic deed which can be used as written evidence, therefore in making a notary deed must meet the requirements in order to achieve the authentic 
nature of the deed being made, for example, is the reading of the deed which is intended for the parties know the contents of the deed made and desired by the parties.

The Authentic Deed itself has three evidentiary powers, namely the power of formal proof, which proves between the parties that they have explained what is written in the deed. The strength of material evidence, which proves that between the parties, the events mentioned in the deed have actually occurred. The power of proof is binding, which proves that between the parties and the third party that on the date stated in the deed concerned, they have appeared before a public employee and explained what was written.

However, it is not a secret that notaries are often summoned to court to provide information on deeds or letters that are in dispute. This raises the question whether the Notary has acted inappropriately in accordance with the Laws and Regulations and the Notary's Code of Ethics or whether there is an accident, whether intentional or unintentional, by the parties or one of the parties to try to commit fraud so as to cause harm to the other party by providing information and documents - incorrect document.

In practice, it is often found, if there is a notary deed being disputed by the parties, or other third parties, then the notary is often withdrawn as the party who participated in or helped commit a criminal act, namely making or providing false information on the notary deed. ${ }^{1}$ In this case the notary intentionally or unintentionally, the notary together with the party / party to make deeds with the intent and purpose of benefiting certain parties or parties or detrimental to other parties, which must be proven in court. Notary Deed made according to the wishes of the parties concerned in order to ensure or guarantee the rights and obligations of the parties, certainty, order and legal protection of the parties. In essence, the notary deed contains the formal truth in accordance with what the parties are notifying to the public official (Notary). The notary is obliged to include in the deed what is truly understood in accordance with the wishes of the parties and read out to the parties about the contents of the deed.

In reality, in the community, it is found that there are parties who deliberately provide data and information that are not in accordance with the reality to a notary in making a deed. This had an impact on the deed he made which later became problematic. Problems arise in the form of notary accountability for the process of making authentic deeds whose data and information are falsified by the parties. The Law on Notary Position and the Law on Amendments to the Law for Notary Public Affairs do not regulate the criminal responsibility of a notary

\footnotetext{
${ }^{1}$ Habib Adjie, 2008, Notarial Law in Indonesia-Thematic Interpretation of Law No.30 of 2004 concerning the Position of Notary Public, Refika Aditama, Bandung, p. 24.
} 
from a deed he has drawn up based on data and information falsified by the parties. As a result, there is a vacuum of legal norms in the Law on Amendments to the Law on Notary Position relating to the responsibilities of notaries in making deeds based on data and information falsified by one of the parties.

Based on the background stated above, the authors are interested in carrying out further research which will be outlined in the form of research with the title: "Notary Responsibilities in terms of making authentic deeds based on forgery of letters by one of the parties".

\section{Research methods}

The approach method in this research is empirical juridical method. The specification of this research is descriptive analytic. The data in this study are primary data and secondary data. Qualitative descriptive data analysis method.

\section{Results and Discussion}

\subsection{Responsibilities of the Notary in the Case of Falsification of Letters by one of the Parties in Preparing the Authentic Deed}

The position of a Notary is present in the community with the will of legal rules in the form of a State as an implementation of the State in providing services to the public with the aim of helping the public in order to provide authentic written evidence regarding conditions, events or legal actions and an authentic evidence recognized by the State. ${ }^{2}$ Notary as an office, and each position in this country has its own authority. Each authority must have a clear legal basis. If an official takes an action beyond his / her authority, it is called an act of breaking the law. An authority does not just appear, but an authority must be expressly stated in the relevant laws and regulations.

Prohibition for notaries is an action that is prohibited from being carried out by the notary, and if this is violated, the relevant notary may be subject to sanctions. Notary has an area with one province and has a domicile in one city or one regency in that area. Notaries are prohibited from leaving the notary's domicile for more than 7 (seven) working days, and notaries are not authorized to regularly perform positions outside their place of domicile.

Responsibility is a consequence that arises as a result of actions carried out by individuals. The ability to be responsible theoretically must fulfill the elements which consist of:

a. the ability to distinguish between good and bad deeds, which are in accordance with the law and those that are against the law;

2

Paulus Effendi Lotulung, Legal Protection for Notaries as General Officials in Carrying Out Their Duties, Bandung, 2003, p. 2. 
b. the ability to determine his will according to conviction about the good and bad of the action.

In essence, all actions that are carried out by individuals, whether intentional or unintentional in the end, must be held responsible especially if the act is related to a position or profession. Responsibility is a principle of professionalism which is a manifestation of a commitment that must be owned by a notary public. against the implementation of his position as stipulated in UUJN.

Acts violating the law and mistakes, each of which is a necessary condition and together is a sufficient condition for the existence of responsibility under article 1365 of the Civil Code. ${ }^{3}$ In the existing doctrine regarding responsibility for harm caused to others, it can be divided into three theories, namely:

a. Liability for mistakes (sculd aansprakelijkheid)

Error here is given a broad meaning which also includes the nature of breaking the law, the person who causes harm to others is responsible as long as the loss is the result of a violation of a norm and the perpetrator can regret violating these norms.

b. Responsibility with proof reversal

The aggrieved party is obliged to prove that the perpetrator has committed an act of breaking the law, so here the violation of norms is considered to exist and furthermore obliges the perpetrator to eliminate this assumption or suspicion to show that he has not violated the law.

c. Responsible risk

A superior is responsible for losses committed by illegal acts by his subordinates committed within the scope of his duties.

The notary's responsibility adheres to the principle of responsibility based on fault (based on fault of liability). The principle of responsibility based on mistakes must fulfill four main elements, namely:

a. there is an act

b. there is an element of error

c. any losses suffered

d. there is a causal relationship between errors and losses

The above error is an element that is against the law. The responsibility of a notary public arises if there is an error made in the performance of his / her job duties and the error causes losses to the person requesting the services of the notary public. Actions that violate the law by a notary, are not only actions that directly violate the law, but also actions that directly violate other regulations, namely regulations that fall within the scope of morality, religion and courtesy in

\footnotetext{
${ }^{3}$ Article 1365 of the Civil Code states that every act that violates the law, which brings harm to another person, obliges the person who due to his wrongdoing to issue the loss, to compensate the loss.
} 
society. ${ }^{4}$ The notary's responsibility occurs in relation to the implementation of duties and obligations borne by the notary based on the authority granted by law. The notary's responsibility arises because of an error committed by the notary in carrying out his / her job duties, so that from the error there may be losses for the party requesting notary services.

Duties or obligations that are based on legitimate authority, either originating from law or from an agreement can result in responsibility for the executor of the obligation. Every granting of an authority is always followed by an obligation or responsibility thereof. Notary is given the authority to make an authentic deed, therefore the notary concerned is obliged to fulfill all the requirements that have been determined, especially in making the deed so that the deed fulfills all the requirements. requirements as an authentic deed. Consequences that arise for a notary as a public official who is given the authority in making authentic deeds, then he must be responsible and if there is a violation or deviation of the deed making requirements,

If the Notary Public as a public official in carrying out his / her authority makes authentic deeds regarding all actions, agreements and stipulations in accordance with statutory regulations, then the Notary as a public official cannot be held accountable from a legal perspective for the deed he has drawn up. However, if it is related to the provisions of Article 84 UUJN, the deed made by the notary does not have notarial power as an authentic deed, but only has the power of proof as a deed under hand or a deed becomes null and void by law. The deed made by a Notary has the power as a deed under hand, if the deed has no or less subjective conditions, including the parties or parties who are not capable of acting in law, whereas the deed becomes null and void if the deed does not meet the objective requirements, for example there is no object agreed upon or the deed is made contrary to law, public order or morals. In such conditions, the notary can be held accountable from a legal point of view. Regarding the accountability of the Notary from a legal point of view, it cannot be separated from the responsibility in terms of criminal, civil and administrative law. This is in line with the prevailing principle that anyone who is injured has the right to make a claim or lawsuit. A lawsuit against a Notary can occur if the issuance of the Notary's deed is not in accordance with the procedure so that it causes losses. On the other hand, if a deed is canceled, the Notary concerned can be held accountable according to Civil Law.

\section{Responsibilities from a Civil Law point of view}

Civil sanctions are sanctions imposed on mistakes that occur as a result of default or actions that violate the onrechtmatige daad law. Civil sanctions can be in the form of reimbursement of expenses, compensation and interest. The notary will

\footnotetext{
${ }^{4}$ R. Wirjono Prodjodikiro, Acts against the Law seen from the point of Civil Law, Mandar Maju, Bandung, 2000, p. 6.
} 
be asked for sanctions if he gets a lawsuit from the parties who feel that the deed is legally flawed, so that it has the power of evidence as an underhand deed or is null and void by law.

Notary deed has perfect evidentiary power, but if certain provisions are violated, the evidentiary value will be degraded into an underhand deed. Article 1869 of the Civil Code determines that a notary deed that has the power to act as an underhand deed can occur if it does not meet the following conditions:
a. the official is not authorized
b. does not have a public official concerned
c. defect in shape

Underhanded deeds have perfect evidentiary value as long as the parties admit it. If the parties violate certain provisions as stated in the UUJN, then the deed concerned still has perfect evidentiary power and binds the parties.

A deed that is declared null and void, then the deed is deemed never to exist or has never been made, something that has never been made cannot be used as the basis for a claim in the form of compensation for losses which usually consists of compensation for expenses, compensation and interest. null and void cannot be requested to provide reimbursement of expenses, compensation and interest.

Reimbursement of expenses, compensation and interest can be sued against the notary based on the legal relationship of the notary with the parties dealing with the notary. If there is a party who feels aggrieved from the deed made by the notary, then the person concerned can directly file a civil claim against the notary public. so that the notary public is liable for the deed he has drawn. Claims for compensation, compensation and interest against the notary are not based on the changed position of evidence because they violate certain provisions in the Law on the Position of Notary Public, but are based on the legal relationship that occurs. between the notary and the parties who appear before the notary public. Even though the notary is retired,The notary must still be responsible for the civil case of the deed he has made.

In practice, a notary is often made or seated as a defendant by another party, who feels that the legal action he committed in the deed is categorized as an act or legal act of the notary together with other parties who are also mentioned in the deed. In the context of notary law, the notary's task is only to formulate the wishes of the parties in the form of an authentic deed, with due observance of the applicable law. Based on this substance, it is clear that if the deed made by the notary is problematic by the parties themselves, then the notary does not need to be involved in this matter. this is because the notary is not a party to the deed.

The denial can be done by filing a civil suit against the notary to court, and the parties are obliged to prove the things they want to deny, while the notary is obliged to defend these aspects. In this case, it is necessary to understand the 
rule of notary law, namely notary deed as an authentic deed, where the deed has perfect evidentiary power, so that if there is a person or party who wants to deny it or states that the deed is not true, then that party is obliged for him to prove his assessment or the statement is in accordance with the applicable legal rules.

In accordance with the legal construction of the position of a notary in Indonesia, the first is that the Notary is not a party to the deed, and the notary only formulates the wishes of the parties so that their actions are written in the form of an authentic deed, namely deeds drawn up by and before a notary. Based on such a legal construction, it is very difficult to accept based on logic if a notary is made a defendant in connection with the deed made before the notary. The notary has the authority to carry out his duties as long as the authority is attached to him. The notary's liability limit is as long as the notary has the authority A notary who is on leave, retired and who has been dismissed cannot be held accountable anymore, because he no longer has authority. ${ }^{5}$

Deeds made by a notary relating to civil matters, namely regarding an agreement made by two or more parties even though it is possible to make it unilaterally (its nature only strengthens). The nature and principles adhered to by the law of engagement, especially an agreement that is born because of an agreement, that the law is only possible and may be changed or replaced or declared invalid, only by those who make it, meaning that the agreement of the two parties as stated in an authentic deed binds the two both parties as binding on law.

Article 84 of the Law on the Position of Notary Public stipulates that "it can be an excuse for the party suffering a loss to demand reimbursement of expenses, compensation and interest from the Notary Public". In this case, the Notary as the official deed maker, if there is an error either intentionally or due to negligence it results in other people (as a result of making the deed) suffer losses, which means that the Notary has committed an unlawful act. As stated in Article 84 of the Notary Position Law, that the act of violation committed by a Notary against the provisions as referred to in several articles, then if one of these articles is violated it means that an act has violated the law, so the element must have an act of violating the law has been fulfilled.

\section{Responsibilities in terms of Administrative Law}

In addition to civil and criminal sanctions imposed on notaries for committing violations, there are also administrative sanctions. Administrative sanctions for notaries regulated in Article 85 of the Law on Notary Position have been determined as follows:
a. verbal warning
b. written warning
c. temporary stop

\footnotetext{
${ }^{5}$ Habib Adjie, Indonesian Notary Law, Op.cit., p. 23.
} 
d. honorific dismissal

e. disrespectful dismissal

Sanctions against notaries in the form of temporary dismissal from their positions are intended to prevent the notary from carrying out his / her duties for a while before the sanctions in the form of honorific dismissal or disrespectful dismissal are imposed on the notary. This sanction may end in the form of restoration to the notary to carry out his duties again or be followed up with To provide certainty, a time limit must be determined so that the fate of the notary is not hanged. This temporary dismissal sanction is real compulsion, while the sanction of respectful dismissal or disrespectful dismissal falls into the realm of sanctions. rationing of favorable decisions.

\section{Responsibilities from a Criminal Law Point of View}

According to Mr. Harapan Kanna, SH. Mkn. (Notary / PPAT Kota Makassarr) The notary's criminal responsibility for the deed he makes is not regulated in the Law on Amendment to the Notary Office Law, but the notary's criminal responsibility is imposed if the Notary commits a criminal act. The relevant notary cannot be held accountable, because the notary only records what is conveyed by the parties to be recorded in the deed. False information submitted by the parties is the responsibility of the parties. In other words, what can be accountable to the Notary is if the fraud or deception originates from the Notary himself. The Law on Amendment to the Law on the Position of Notary Public only regulates sanctions for violations committed by a Notary against the Law on Amendments to the Law on the Position of Notary Public. These sanctions can be in the form of deeds made by Notaries that do not have authentic power or only have power as deeds in under the hand. For the sake of upholding the law, Notaries must comply with the criminal provisions as regulated in the Criminal Code, and to their implementation considering that the Notary commits an act in his capacity to differentiate from the Notary's act as a legal subject of a person Article 50 of the Criminal Code provides legal protection for a Notary stating that: "whoever commits an act to carry out the statutory regulations, they cannot be punished $" .6$

In practice, it is found that the violation of the sanction then qualifies as a criminal act committed by a notary public. This aspect is closely related to the Notary's act of violating Article 15 of the Law on Amendments to the Law on Notary Office, where the outcome is that if the Notary does not carry out the provisions of the article it will lead to forgery or falsification of deeds as referred to in Articles 263, 264, and 266 of the Criminal Code so that it can cause losses to interested parties. With this, it creates confusion as to whether it is possible that the notary intentionally culpa or made a mistake together with the parties to

\footnotetext{
${ }^{6}$ The results of the interview with Harapan Kanna SH, M.kn as Notaris / PPAT in Makassar City, on January 14, 2020 at 11.00 WITA.
} 
make a deed that is intended to commit a criminal act. If the notary is proven to have violated.

\subsection{Criminal Liability by a Notary If Losses Arise on One of the Parties as a Result of Fake Documents from One of the Parties}

According to Moeljatno, a criminal act is an act that is prohibited by a prohibition law which is accompanied by a threat (sanction) in the form of a certain crime, for whoever violates the prohibition. It can also be said that a criminal act is an act which is prohibited by a legal rule and is punishable by only predicate punishment in that it is remembered that the prohibition is aimed at an act, (i.e. a situation or event caused by a person's behavior), while the threat of punishment is aimed at the person who caused it. that incident. There is a close relationship between prohibition and the threat of punishment, because between the incident and the person who caused the incident, there is also a close relationship. Which cannot be separated from the others. Therefore, for the existence of a criminal act there must be the following elements:
a. Deeds (human)
b. Which meet the formulation in the law (constituting a formal requirement), and
c. Is against the law (a material requirement).

A criminal act does not stand alone, it only has meaning if there is criminal responsibility. This means that every person who commits a criminal act does not automatically have to be convicted. To be convicted, there must be criminal responsibility. Criminal liability is born with the forwarding of an objective reproach (verwijbaarheid) to an act that is declared a criminal offense under the applicable criminal law, and subjectively to the maker who meets the requirements to be subject to punishment for the act. ${ }^{7}$

Regarding the criminal responsibility of a notary public, the question that arises is, in what way can a notary be held liable if he makes a deed based on false information? The answer to this question, of course, must refer to the applicable regulations. Referring to the prevailing regulations, it is known that a notary public can be held liable for criminal responsibility in terms of making deeds based on false information, and the rules related to the above issues are Article 263 paragraph (1), 264 paragraph (1) 1st, or 266 paragraph (1) of the Criminal Code jo. Article 55 paragraph (1) of the Criminal Code. Meanwhile, the provisions of the Law on Notary Position do not regulate criminal acts committed by notaries.

To be held accountable criminally, according to Mr. Harapan Kanna SH. Mkn (Notary / PPAT Makassar City), a notary must meet the following elements:

\footnotetext{
${ }^{7}$ Elucidation of Article 36 of the 2005 Draft Criminal Code
} 
a. Committing a criminal act. In this case, a notary is suspected of having committed a criminal act which resulted in the issuance of a notary deed based on false information. Without a criminal act, it is impossible for a notary to be held accountable under the criminal law.

b. Have the ability to be responsible. To be held accountable under criminal law, a notary must have the capacity to be held accountable.

c. Deliberately or negligently. Criminal acts committed by a notary in the case of making deeds based on false information can be in the form of deliberate action or negligence. In order to be held responsible for a criminal act, a notary must have an error, whether it was done intentionally or because of negligence.

d. There is no excuse for forgiveness. A notary public can be held responsible for the crime if there is no excuse. If in the case of making a deed based on false information that is suspected of involving a notary public, there is no excuse found in the notary concerned, then he may be held responsible for the crime. ${ }^{8}$

Thus, notaries can be held responsible for criminal acts related to deeds that are based on false information if the actions of the notary meet the formulation of the elements of falsification in the Criminal Code, especially Article 264 paragraph (1) 1 of the Criminal Code, namely the deed of relaas or deed of officials (ambtelijke deed), but the notary cannot be held responsible for the notary's criminal responsibility for the party deed (partijn akten) based on Article 266 paragraph (1) in conjunction with Article 55 paragraph (1) of the Criminal Code.

The Law on Notary Position does not regulate criminal acts related to the position of notary public, so there is no provision in the Law on Notary Office that can be used as the basis for a notary's criminal liability. Notaries can be held liable under Article 264 paragraph (1) 1st of the Criminal Code if deliberately or negligently in making deeds of relaas or official deeds (ambtelijke akten), namely deeds made by (door enn) notaries based on the notary's observations, so that detrimental to other parties, but still heed the function and authority of a notary based on UUJN, as an official appointed by the state in serving the public in making authentic deeds which are evidence to guarantee legal certainty.

To be held responsible criminally, a notary must fulfill the following elements: committing a criminal act; have the ability to be responsible; deliberate or negligent; and there are no excuses for forgiveness.

\section{Closing}

\subsection{Conclusion}

\footnotetext{
8 Results of interview with Harapan Kanna SH, M.kn as Noatris / PPAT in Makassar City, on January 18,2020 at 11.00 WITA
} 
Notaries are responsible in accordance with their actions, both responsibilities in terms of Administrative Law, Civil Law, namely according to the provisions of the sanctions stated in Articles 84 and 85 of the Law on Amendments to the Law on Notary Position and the code of ethics, but in the Law The Position of Notary Public and the Law on Amendments to the Law on the Position of Notary Public do not provide for any criminal sanctions. In practice, it is found that the violation of the sanction then qualifies as a criminal act committed by a notary public. The aforementioned aspect is closely related to the Notary's act of violating Article 15 of the Law on Amendments to the Law on the Position of Notary, where the outcome is that if the Notary does not comply with the provisions of the article, it will result in an act of forgery or falsification of the deed as referred to in Articles 263, 264 and 266 of the Criminal Code so that it may cause losses to the interested parties. And a Notary Public cannot be held responsible for a criminal case if there is a loss to one of the parties as a result of a false document from one of the parties according to the Law on Notary Office because the Notary only records what the parties convey to be written into a deed. False information submitted by the parties is the responsibility of the parties. And a Notary Public cannot be held responsible for a criminal case if there is a loss to one of the parties as a result of a false document from one of the parties according to the Law on Notary Office because the Notary only records what the parties convey to be written into a deed. False information submitted by the parties is the responsibility of the parties. And a Notary Public cannot be held responsible for a criminal case if there is a loss to one of the parties as a result of a false document from one of the parties according to the Law on Notary Office because the Notary only records what the parties convey to be written into a deed. False information submitted by the parties is the responsibility of the parties.

\subsection{Suggestion}

In order for the government as the executive body and the House of Representatives (DPR) as the legislative body to reconstruct the regulations in the Law on Amendments to the Law on Notary Office regarding the absence of commulating or merging the application of sanctions as a form of accountability for a Notary Public, because of the regulation of the application of sanctions. This of course will provide more protection and legal certainty for the aggrieved parties, including the Notary itself. And it is necessary to revise the Law on Amendments to the Law on the Position of Notary Public to reinforce the actions prohibited by Notaries in carrying out their duties, including provisions in making deeds for both Notaries and parties wishing to make deeds. 


\section{References}

Journals:

Aryani Witasari, 2012, MPD is Not a Notary Advocate Based on Act No. 30 of 2004 concerning the Position of Notary, Journal of Law, Volume 28, Number 2. Accessed on: December 15, 2020 at 20.00 WITA.

Rahmad Hendra, 2012, The Notary's Responsibility Against Authentic Deeds That Are Using False Identities In Pekanbaru City, Journal of Law, Volume 3, Number 1. Accessed on: December 20, 2021 at 21.00 WITA.

http://sekedarkabar.blogspot.com/2012/05/pengentuk-tanggungresponsibility.html Accessed on: December 10, 2020 at 20.00 WITA.

Books:

Habib Adjie. (2008). Notary Law in Indonesia-Thematic Interpretation of Act No. 30 of 2004 Concerning the Position of Notary Public, Bandung: Refika Aditama

Paulus Effendi Lotulung. (2003). Legal Protection for Notaries as General Officials in Carrying Out Their Duties, Bandung

R. Wirjono Prodjodikiro. (2000). Acts Violating the Law in terms of Civil Law, Bandung: Mandar Maju, 